Семененко В. М., к.т.н., с.н.с.;

Антоненко C. I.

Центр воєнно-стратегічних досліджень Національного університету оборони України імені Івана Черняховського, Київ

\title{
Аналіз основ стратегічного керівництва Збройними Силами України, іншими складовими сил оборони
}

Резюме. У статті проаналізовано існуючу систему стратегічного керівництва Збройними Силами України та іншими військовими формуваннями.

Ключові слова: стратегічне керівництво, система управління.

Постановка проблеми. Проведене в рамках комплексного огляду сектору безпеки i оборони України оцінювання стану воєнної безпеки держави виявило низку проблем у стратегічному керівництві Збройними Силами та іншими складовими сил оборони України: відсутність об'єднаного керівництва силами оборони, яке здійснювалося б відповідно до принципів і стандартів, прийнятих державамичленами НАТО; відсутність чіткого розподілу відповідальності за формування та застосування сил оборони, що негативно позначається на здатності керівництва держави ефективно управляти сферою оборони; низьку ефективність системи оперативного (бойового) забезпечення, зв'язку, розвідки; надмірність обсягів та неактуальність нормативно-правової бази у сфері оборони; відсутність автоматизованої системи управління матеріально-технічним забезпеченням [1-3], а також організації міжвідомчого угруповання військ (сил) та управління ним [4].

Аналіз наявних науково-методичних підходів, шляхів та механізмів розв'язання зазначених проблем удосконалення процесу стратегічного керівництва 3С України, іншими складовими сил оборони відповідно до принципів і стандартів НАТО та його впровадження, алгоритму взаємодії його суб' єктів, обгрунтування рекомендацій щодо подальшого його розвитку в сучасних безпекових умовах та на перспективу, розроблення і вдосконалення необхідної для цього законодавчої бази залишається актуальною науковою проблемою, яка потребує розв'язання у найближчій перспективі.

Аналіз стратегічним керівництвом Збройними Силами України, іншими складовими сил оборони відповідно до принципів і стандартів HАTO розглянуто в публікаціях В. П. Бочарнікова, М. М. Дєнєжкіна, М. М. Лобка, С. М. Нечхаєва, Ю. В. Пунди, I. С. Романченка, I. С. Руснака, Ф. В. Саганюка, С. В. Свєшнікова, В. М. Телелима, P. І. Тимошенка, В.С. Фролова та інших фахівців. Автори цих праць розглядають загальні підходи до існуючої системи державного управління процесами формування i реалізації оборонної політики України, розкривають питання геополітичних аспектів забезпечення обороноздатності України, наводять концептуальні основи забезпечення обороноздатності держави, вказують на необхідність зосередити головні зусилля науковців і практиків на формуванні основ переходу на стандарти НАТО, створенні відповідної нормативно-правової бази, впровадженні нового понятійно-категорійного апарату, визначенні базового переліку військових стандартів НАТО, які доцільно врахувати.

У той же час недосконалість законодавчої бази, недостатність опрацювання методологічних засад у сфері національної безпеки i оборони України зумовлює відсутність загальних та системних правових основ для формування i розвитку сектору безпеки i оборони України, не забезпечує підтримання спроможностей сил оборони на належному рівні, який гарантував би їх високу бойову готовність і боєздатність щодо відбиття збройної агресії проти України, допускає неефективне використання державних ресурсів, виділених для підтримання бойової готовності, у тому числі боєздатності військ (сил), що задіяні в антитерористичній операції (АТО).

Метою статті $\epsilon$ узагальнення й аналіз проблем стратегічного керівництва Збройними Силами України та іншими військовими формуваннями. 
Виклад основного матеріалу. Система стратегічного керівництва Збройними Силами України $€$ складовою системи керівництва державою, що визначено Конституцією та низкою законів України. Відповідно до Конституції України Президент України $\epsilon$ главою держави i “здійснює керівництво у сферах національної безпеки та оборони держави" [5]. У цьому контексті слід наголосити, що згідно зі ст. 106 Конституції України "Президент України не може передавати свої повноваження іншим особам або органам". Це важливе положення, яке пояснює, чому у Президента України як глави держави немає віце-президента чи заступників, а такі органи, як Рада національної безпеки i оборони (РНБО) України, Ставка Верховного Головнокомандувача (ВГК) й інші $є$ тільки координаційними органами при ньому.

Конституція України наділяє Президента України як Верховного Головнокомандувача Збройних Сил України (п. 17 ст. 106) правом “прийняття рішення про використання Збройних Сил України у разі збройної агресії проти України" (п. 19 ст. 106) [5].

На розвиток положень Конституції України у низці законів України визначено й інші повноваження Президента України щодо керівництва Збройними Силами України, наприклад, у Законі України "Про Збройні Сили України": "Керівництво Збройними Силами України в межах, передбачених Конституцією України, здійснює Президент України як Верховний Головнокомандувач Збройних Сил України" (ст. 7) [6].

Крім того у ст. 4 Закону України "Про оборону України" вказано: "У разі збройної агресії проти України або загрози нападу на Україну Президент України приймає рішення про ... застосування Збройних Сил України, інших військових формувань, утворених відповідно до законів України..." [7], тобто Президент України як Верховний Головнокомандувач Збройних Сил України не здійснює безпосереднє управління операціями (бойовими діями) утворених угруповань військ (сил), а “приймає рішення про ... застосування Збройних Сил України, інших військових формувань". Отже, посада Президента України і Верховного Головнокомандувача Збройних Сил України має на меті об'єднати політичне i військове керівництво у державі у разі війни та спрямувати застосування військової сили на досягнення політичних цілей у відстоюванні національних інтересів держави.

Оборона держави політичними, економічними, соціальними, інформаційними та іншими заходами містить воєнну складову, що передбачає вироблення воєнної політики із забезпечення воєнної безпеки і відбиття збройної агресії проти України. Керівництво відбиттям збройної агресії є особливим видом управлінської діяльності, що потребує спеціальних знань, навичок та досвіду i викликає необхідність створення окремого органу управління при Президентові України зі специфічними функціями. На сьогодні таким органом визначено Ставку ВГК.

Ставку ВГК утворюють як вищий колегіальний орган військового керівництва обороною держави для забезпечення стратегічного керівництва Збройними Силами України, іншими військовими формуваннями та правоохоронними органами в особливий період (в сучасних умовах можна говорити про забезпечення стратегічного керівництва Збройними Силами України та іншими складовими сил оборони) (ст. 8) [7]. За результатами розгляду на засіданнях Ставки ВГК визначених питань Президент УкраїниВерховний Головнокомандувач Збройних Сил України приймає відповідне рішення (при цьому, голосування не проводиться). Рішення набувають чинності згідно 3 директивами та наказами Верховного Головнокомандувача Збройних Сил України і $є$ обов' язковими для виконання.

Таким чином, Ставка ВГК - це важливий $\mathrm{i}$ необхідний елемент системи управління державою, орган військового керівництва обороною держави в особливий період, призначений забезпечувати стратегічне керівництво Збройними Силами України, іншими військовими формуваннями та правоохоронними органами в особливий період.

Існуючу систему стратегічного керівництва Збройними Силами України та іншими складовими сил оборони відповідно до чинного законодавства наведено на рис. 1.

Кабінет Міністрів України (КМУ) є вищим органом у системі органів виконавчої влади (ст. 113), що “спрямовує і координує роботу міністерств, інших органів виконавчої влади" (ст. 116). Кабінет Міністрів України відповідальний перед Президентом України і Верховною Радою України, підконтрольний i підзвітний Верховній Раді України у межах, передбачених Конституцією України (ст. 113) [5].

Президент України, що одночасно $\epsilon$ i Головою РНБО України, може впливати на Прем'єр-міністра України, віддаючи йому доручення як члену РНБО України, та КМУ, для якого рішення РНБО України щодо забезпечення заходів у сфері національної безпеки і оборони $\epsilon$ обов'язкові для виконання. 


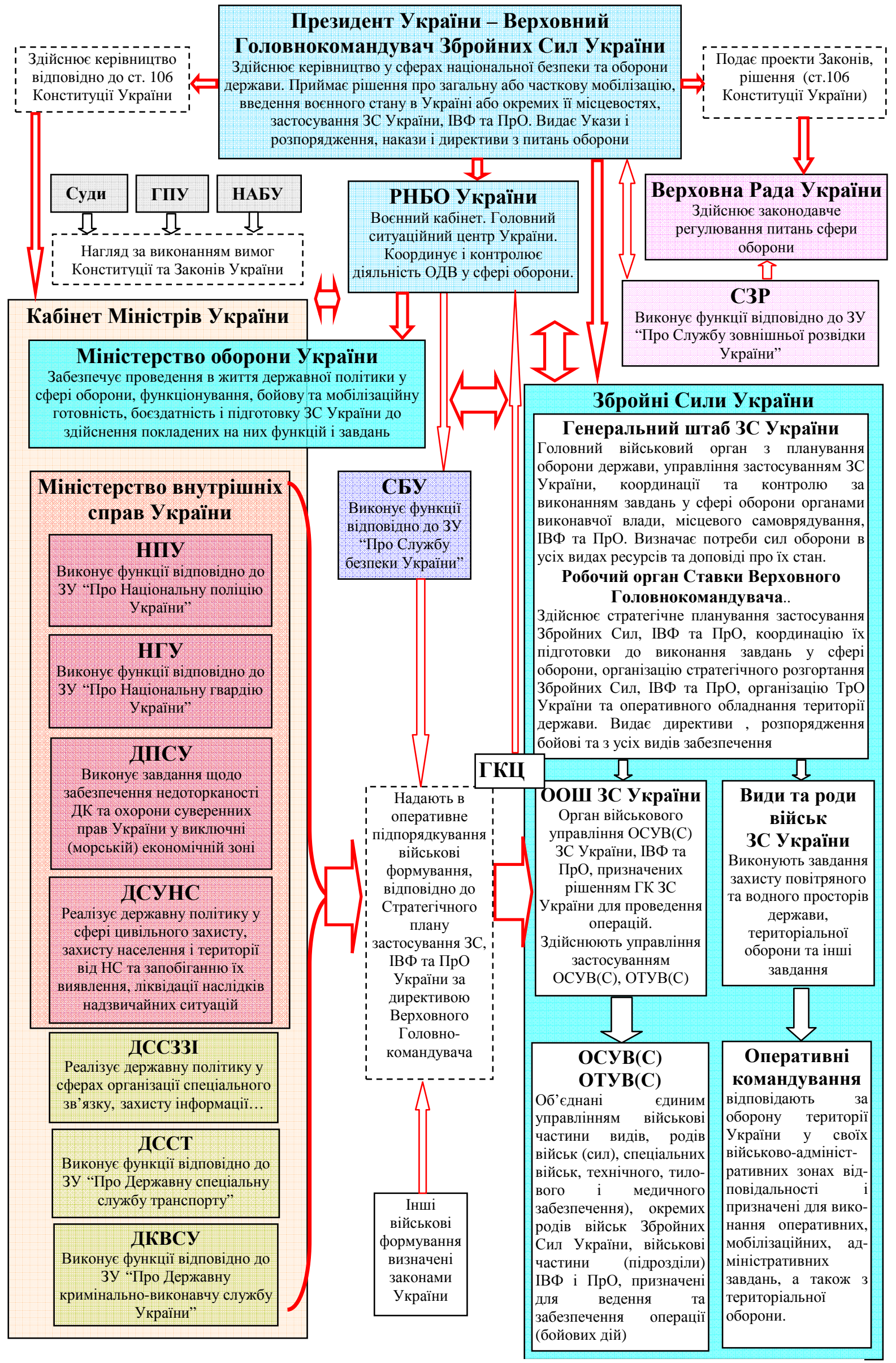

Рис. 1. Існуюча система стратегічного керівництва ЗС України та іншими складовими сил оборони 
Кабінет Міністрів України $є$ колегіальним органом, який очолює Прем'єрміністр України. Міністр оборони України $\epsilon$ членом КМУ і підпорядковується Прем'єрміністру України, а не Президенту України, як це визначено у Стратегічному оборонному бюлетені України [4].

Відповідно до вітчизняного законодавства Міністр оборони України $\epsilon$ членом РНБО України, Воєнного Кабінету РНБО України, інших державних органів, але не як підлеглий Президента України, а як член КМУ. При цьому Міністра оборони України призначає Верховна Рада України за поданням Президента України.

Крім того, КМУ є суб'єктом цивільного контролю над Воєнною організацією та правоохоронними органами держави i здійснює цивільний контроль, серед інших, над Збройними Силами України (ст. 5, 6) [8].

Варто зауважити таку особливість, що відповідно до п. 7 ст. 116 Конституції України КМУ “здійснює заходи щодо забезпечення ... громадського порядку, боротьби зі злочинністю". Згідно із Законом України "Про Кабінет Міністрів України" [9] та Положенням про Міністерство внутрішніх справ України [10] Міністерство внутрішніх справ України $\epsilon$ центральним органом виконавчої влади, діяльність якого спрямовується i координується Кабінетом Міністрів України. Ось чому Міністра внутрішніх справ України призначає Верховна Рада України за поданням Прем'єр-міністра України. Звідси іноді виникає колізія щодо діяльності Міністерства внутрішніх справ України, якому підпорядковані Національна гвардія України, Національна поліція України, Державна прикордонна служба України, Державна служба України 3 надзвичайних ситуацій, Державна міграційна служба України, які входять до складу сектору безпеки і оборони України.

Міністерство оборони України центральний орган виконавчої влади, у підпорядкуванні якого перебувають Збройні Сили України. Міністерство оборони України здійснюе військово-політичне та адміністративне управління Збройними Силами України (ст. 3, 10) [6]. Діяльність Міністерства оборони України спрямовується і координується КМУ. Основною функцією міністерства $є$ забезпечення потреб Збройних Сил України за рахунок державних ресурсів, наявних у розпорядженні КМУ, для набуття ними спроможностей щодо виконання визначених Конституцією і законами України завдань.

Верховна Рада України $є$ органом законодавчої влади в Україні та не здійснює керівництво Збройними Силами України.

Однак Верховна Рада України в межах повноважень, визначених Конституцією України, законодавчо регулює питання сфери оборони, відповідно і діяльності ЗС України, а також “схвалює рішення Президента України про використання ЗС України у разі збройної агресії проти України" (п. 9 ст. 85) [5]. Крім того, Верховна Рада України є суб' єктом цивільного контролю над Воєнною організацією та правоохоронними органами держави i, серед інших, здійснює парламентський контроль над Збройними Силами України (ст. 6) [8].

Рада національної безпеки i оборони України $€$ координаційним органом 3 питань національної безпеки i оборони при Президентові України.

Однак РНБО України не має владних повноважень (зокрема 3 питань стратегічного керівництва Збройними Силами України), i тому іiі рішення набувають чинності згідно 3 указами Президента України, які стають обов'язковими для виконання органами виконавчої влади, у т.ч. Міністерством оборони України, а отже, і Збройними Силами України, які перебувають у його підпорядкуванні.

Фактично за допомогою РНБО Президент України як глава держави, реалізовує визначені йому Конституцією України повноваження щодо керівництва у сферах національної безпеки і оборони держави.

Воєнний кабінет РНБО України $є$ робочим органом Ради національної безпеки $\mathrm{i}$ оборони України в особливий період [12]. Воєнний кабінет підвищує значущість, деталізує та конкретизує повноваження РНБО України 3 питань збройної боротьби за відсутності Ставки ВГК в умовах проведення ATO, а також визначає порядок формування i функціонування "структур сектору безпеки i оборони України”. Його завдання i повноваження поєднують завдання i повноваження РНБО України та Ставки ВГК.

Воєнний кабінет не має владних повноважень, однак, надає пропозиції в РНБО України, на своїх засіданнях приймає рішення 3 питань своєї компетенції шляхом відкритого голосування більшістю від його складу. Прийняті рішення, оформлені протоколами, можуть бути надіслані для розгляду центральним та місцевим органам виконавчої влади, органам військового управління, 
правоохоронним органам, військовоцивільним адміністраціям. Отже, Воєнний кабінет РНБО України може здійснювати певні повноваження опосередковано, через своїх членів- Міністра оборони України i начальника Генерального штабу Головнокомандувача Збройних Сил України.

Генеральний штаб Збройних Сил України - головний військовий орган 3 планування оборони держави, управління застосуванням 3С України, координації та контролю за виконанням завдань у сфері оборони органами виконавчої влади, органами місцевого самоврядування, військовими формуваннями, утвореними відповідно до законів України, та правоохоронними органами у межах, визначених Законом України "Про оборону України", іншими законами України i нормативно-правовими актами Президента України, Верховної Ради України та Кабінету Міністрів України. Генеральний штаб 3С України в особливий період є робочим органом Ставки Верховного Головнокомандувача (ст. 11) [7].

Начальник Генерального штабу Головнокомандувач Збройних Сил України здійснює безпосереднє військове керівництво 3С України (ст. 8) [6].

Як показала практика, існуюча система стратегічного керівництва ЗС України функціонувала в умовах мирного часу i певною мірою забезпечувала керівництво 3С України та підготовку держави до оборони. Були опрацьовані стратегічний замисел, план застосування ЗС України, інших військових формувань i правоохоронних органів, плани мобілізації, територіальної оборони, документи оборонного планування, розвитку ЗС України, повсякденної діяльності тощо.

Поряд 3 цим, як показав досвід участі ЗС України в АТО, найбільш проблематичним в управлінні 3С України є поєднання для ГШ 3С України, інших органів військового управління 3С України виконання значного обсягу функцій i завдань повсякденної діяльності та управління застосуванням ЗС України.

Крім того, проведене дослідження виявило низку проблемних питань в організації стратегічного керівництва силами оборони сектору безпеки і оборони України, зокрема:

3 початком воєнної агресії Російської Федерації проти України система управління усіма сферами держави, у тому числі силами оборони, не переведена на режим функціонування в умовах правового режиму воєнного стану (особливого періоду). Це значно ускладнює дослідження, вивчення та аналіз ефективності стратегічного керівництва силами оборони сектору безпеки i оборони України на практиці;

$$
\text { аналіз організації управління }
$$
угрупованнями військ (сил) у ході АТО на Сході України показує низьку ефективність оперативних командувань. Реальні загрози Росії щодо повномасштабної агресії потребують розгляду доцільності відновлення армійських корпусів та формування оперативно-стратегічного угруповання під керівництвом командувача об'єднаних сил на території південно-східних областей України;

повноваження РНБО України, визначені Конституцією України та Законом України "Про Раду національної безпеки i оборони України", наявність у пї складі Воєнного кабінету визначають необхідність проведення додаткового дослідження щодо доцільності створення Ставки Верховного Головнокомандувача в особливий період;

для вивчення методичних підходів та досвіду реформування системи стратегічного керівництва сектором безпеки i оборони України необхідно брати за приклад держави, які за воєнними традиціями, рівнем економічного розвитку, воєнного потенціалу, роллю і місцем у геополітичному просторі та наявними загрозами у воєнній сфері схожі 3 Україною.

Разом перелічені проблеми і недоліки стратегічного керівництва ЗС України значно перешкоджають ефективній роботі МО України і ГШ ЗС України, інших органів військового управління ЗС України щодо виконання покладених функцій i завдань 3 управління військами (силами) 3С України.

У ході проведення АТО було виявлено низку недоліків у документах нормативноправової бази, деякі неточності або недостатнє висвітлення базових питань. Унаслідок цього 3'явилась необхідність проаналізувати документи i надалі їх удосконалити, зокрема стосовно визначення органу управління силами оборони сектору безпеки і оборони України, а також механізму управління ними.

У Воєнній доктрині України (п. 25) [2] наведено механізм залучення інших складових сектору безпеки і оборони України (СБіО), а саме:

рішення про застосування (залучення) 3С України, Державної служби спеціального зв'язку та захисту інформації України, Державної спеціальної служби транспорту, інших утворених відповідно до законів України 
військових формувань, правоохоронних органів спеціального призначення у разі зовнішньої агресії, внутрішнього збройного конфлікту чи масштабних проявів тероризму приймає Президент України згідно зі своїми повноваженнями;

об'єднаний комітет 3 питань розвідувальної діяльності при Президентові України забезпечуватиме координацію діяльності розвідувальних органів України у відповідних сферах (п. 40).

Однак деякі невизначеності вносять інші положення цієї доктрини:

матеріально-технічну базу системи управління СБіО України становитимуть Головний ситуаційний центр України, мережа відомчих ситуаційних центрів, ресурси Антитерористичного центру при Службі безпеки України, Головного центру управління службою Державної прикордонної служби України, аналогічних підрозділів інших складових сектору безпеки і оборони, які будуть реформовані 3 метою досягнення більш високого рівня взаємодії (п. 35);

передбачається розширити можливості

Головного ситуаційного центру України для забезпечення координації i контролю за діяльністю органів виконавчої влади, правоохоронних органів та військових формувань у сфері національної безпеки i оборони у мирний час, в особливий період, в умовах воєнного, надзвичайного стану та у разі виникнення кризових ситуацій, що загрожують національній безпеці України (п. 39).

До питання стратегічного керівництва силами оборони СБіО України додане лише положення про те, що матеріально-технічну базу системи управління сектором безпеки $\mathrm{i}$ оборони України становитимуть Головний ситуаційний центр України і мережа відомчих ситуаційних центрів, що $\epsilon$ не органами управління, а лише аналітичними структурами, на які покладені функції координації і контролю.

Одним зі шляхів розв'язання зазначених проблем (з урахуванням досвіду у світовій практиці) $є$ розподіл функцій МО України і ГШ ЗС України, що забезпечить значне підвищення рівня керівництва Збройними Силами України.

Висновки. Таким чином, у статті проаналізовано питання стратегічного керівництва Збройними Силами України, іншими складовими сил оборони. На сьогодні створення системи стратегічного керівництва Збройними Силами України, іншими складовими сил оборони відповідно до принципів і стандартів, прийнятих у державахчленах НАТО, визначено стратегічною ціллю № 1 оборонної реформи. Система стратегічного керівництва нині перебуває на етапі започаткування, тому визначені проблеми потребують подальшого наукового дослідження. Разом 3 тим, на сьогодні не розроблено методологічних підходів щодо вдосконалення стратегічного керівництва Збройними Силами України та іншими складовими сил оборони. Отже, напрямом подальших наукових досліджень за доцільне визначити розроблення методологічних підходів до вдосконалення стратегічного керівництва Збройними Силами України та іншими складовими сил оборони.

\section{СПИСОК ВИКОРИСТАНОЇ ЛІТЕРАТУРИ}

1. Указ Президента України "Про рішення Ради національної безпеки і оборони України від 6 травня 2015 року “Про Стратегію національної безпеки України” від 26.05.2015 № 287/2015 [Електронний ресурс]. - Режим доступу: www.president.gov.ua/ documents/19521.html.

2. Указ Президента України "Про рішення Ради національної безпеки і оборони України від 2 вересня 2015 року "Про нову редакцію Воєнної доктрини України" від 24.09.2015 № 555/2015 [Електронний peсурс]. - Режим доступу: http://www.president.gov.ua/ documents/555201519443.

3. Указ Президента України "Про рішення Ради національної безпеки $\mathrm{i}$ оборони України від 4 березня 2016 року "Про Концепцію розвитку сектору безпеки і оборони України" від 14.03.2016 № 92/2016 [Електронний ресурс]. - Режим доступу: www.president.gov.ua/documents/92201619832. 4. Указ Президента України "Про рішення Ради національної безпеки і оборони України від 20 травня 2016 року “Про Стратегічний оборонний бюлетень України” від 06.06.2016 № 240/2016 [Електронний ресурс]. - Режим доступу: www.president.gov.ua/ documents/2402016-20137.

4. Конституція України від 28 червня 1996 року.

5. Закон України "Про Збройні Сили України" від 6 грудня 1991 № 1934-XII (зі змінами) [Електронний pecypc]. - Режим доступу: www.zakon2.rada.gov.ua/ laws/show/1934-12.

6. Закон України "Про оборону України" від 06.12.1991 № 1932-XII (зі змінами) [Електронний pecypc]. - Режим доступу: www.zakon3.rada.gov.ua/laws/show/ 1932-12.

7. Закон України "Про демократичний цивільний контроль над Воєнною організацією $\mathrm{i}$ правоохоронними органами держави" від 19.06.2003 № 975-IV.

8. Закон України "Про Кабінет Міністрів України" від 27.02.2014 № 794-VII. 
9. Положення про Міністерство внутрішніх справ України. Затверджене Постановою Кабінету Міністрів України від 28.10.2015 № 878.

10. Закон України "Про Раду національної безпеки і оборони України” // Відомості Верховної Ради України. - 1998. - № 35. - ст. 237.
11. Положення про Воєнний кабінет Ради національної безпеки і оборони України: затв. Указом Президента України від 12.03.2015 №139/2015.

Стаття надійшла до редакції 02.10.2017

\section{Семененко В. М., к.т.н, с.н.с.;}

Антоненко C. I.

Центр военно-стратегических исследований Национального университета обороны Украины имени Ивана Черняховского, Киев

Анализ основ стратегического руководства Вооруженными Силами Украины, другими составляющими сил обороны

Резюме. В статье проанализирована существующая система стратегического руководства Вооруженными Силами Украины и другими составляющими сил обороны.

Ключевые слова: стратегическое руководство, система управления.

\section{Semenenko, Ph.D, senior researcher;}

\section{S. Antonenko}

Center for Military and Strategic Studies of the National Defence University of Ukraine named after Ivan Cherniakhovskyi, Kyiv

Analysis of the foundations of strategic leadership of the Armed Forces of Ukraine, other components of the defense forces

Resume. The article analyzes the existing system of strategic management by the armed forces of Ukraine and other components of the defense.

Keywords: strategic management, management system. 